\title{
HUBUNGAN TINGKAT PENGETAHUAN PERAWATAN LUKA TERHADAP KEPATUHAN PERAWAT DALAM PROSEDUR PERAWATAN LUKA
}

\author{
Lisma Sari, Oscar Ari Wiryansyah \\ Program Studi S1 Keperawatan STIKES Mitra Adiguna Palembang \\ Komplek Kenten Permai Blok J No 9-12 Bukit Sangkal Palembang 30114 \\ Email : lismasari9@gmail.com
}

\begin{abstract}
Abstrak
Kepatuhan seorang perawat dalam melaksanakan prosedur perawatan luka tidak hanya diukur dari pengetahuan perawat tentang perawatan luka, akan tetapi didasarkan pada penilaian dan pengawasan tindakan prosedur. Tujuan penelitian ini untuk mengetahui hubungan tingkat pengetahuan tentang perawatan luka terhadap kepatuhan perawat dalam pelaksanaan prosedur perawatan luka di ruang Instalasi Gawat Darurat (IGD) Rumah Sakit Pusri dan Rumah Sakit Islam Ar-Rasyid Palembang Tahun 2019. Penelitian ini menggunakan metode analitik dengan pendekatan cross sectional. Populasi penelitian ini adalah keseluruhan perawat di Rumah Sakit Pusri dan Rumah Sakit Islam Ar-Rasyid Palembang. Sampel penelitian ini adalah seluruh perawat di Ruang Instalasi Gawat Darurat Rumah Sakit Pusri dan Rumah Sakit Islam Ar-Rasyid Palembang yang berjumlah 30 responden. Pengambilan sampel menggunakan teknik total sampling. Uji statistik yang digunakan adalah Chi Square. Hasil penelitian didapatkan bahwa sebagian besar responden memiliki tingkat pengetahuan cukup yaitu 16 responden (53,3\%), dan patuh sebanyak 24 responden (80\%), ada hubungan antara tingkat pengetahuan tentang perawatan luka terhadap kepatuhan perawat dalam pelaksanaan prosedur perawatan luka di ruang Instalasi Gawat Darurat (IGD) dengan nilai $p$ value $=0,026$ yang berarti $p<\alpha=0,05$. Disarankan bagi pihak rumah sakit agar meningkatkan kualitas pelayanan khususnya praktik keperawatan melalui upaya pengembangan pengetahuan perawat disertai pendidikan dan pelatihan perawatan luka kepada semua perawat.
\end{abstract}

Kata kunci : Pengetahuan, Kepatuhan, Prosedur Perawatan Luka

\begin{abstract}
A nurse's compliance in carrying out wound care procedures is not only measured by the nurse's knowledge of wound care, but is based on the assessment and supervision of procedure actions. The purpose of this study was to determine the relationship of the level of knowledge about wound care to nurse compliance in the implementation of wound care procedures in the Emergency Room Installation of the Pusri Hospital and the Ar-Rasyid Islamic Hospital Palembang in 2019. This study used analytical methods with cross sectional approach. The study population was all nurses at the Pusri Hospital and the Ar-Rasyid Islamic Hospital in Palembang. The samples of this study were all nurses in the Emergency Room Installation at Pusri Hospital and Palembang Ar-Rasyid Islamic Hospital, which totaled 30 respondents. Sampling uses a total sampling technique. The statistical test used is Chi Square. The results showed that the majority of respondents had a sufficient level of knowledge that is 16 respondents (53.3\%), and obedient as many as 24 respondents (80\%), there was a relationship between the level of knowledge about wound care to nurse compliance in implementing wound care procedures in the Installation Room Emergency Department (IGD) with $p$ value $=0.026$ which means $p<\alpha=0.05$. It is recommended for hospitals to improve the quality of services, especially nursing practices through efforts to develop nurses' knowledge along with wound care education and training for all nurses.

Keywords : Knowledge, Compliance, Wound Care Procedures
\end{abstract}

Jurnal Kesehatan dan Pembangunan, Vol. 10, No. 19, Januari 2020 


\section{PENDAHULUAN}

Rumah sakit merupakan institusi pelayanan kesehatan bagi masyarakat dengan karakteristik tersendiri yang dipengaruhi oleh perkembangan ilmu pengetahuan kesehatan, kemajuan teknologi, dan kehidupan sosial ekonomi masyarakat yang harus tetap mampu meningkatkan pelayanan yang lebih bermutu dan terjangkau oleh masyarakat agar terwujud derajat kesehatan yang setinggi-tingginya (UU Rumah Sakit, 2009). Akan tetapi, rumah sakit dapat juga merupakan sumber bagi segala macam penyakit yang berasal dari penderita maupun bagi pengunjung yang berstatus pembawa (carier). Keberhasilan suatu rumah sakit dalam menjalankan fungsinya ditandai dengan adanya peningkatan mutu pelayanan rumah sakit (Andri, 2016).

Pelayanan rumah sakit diharapkan dapat memberikan pelayanan secara optimal yang dapat dicapai dengan memantau kinerja perawat, karena perawat menjadi ujung tombak pelayanan rumah sakit, tetapi sering kali banyak faktor yang mempengaruhi kinerja perawat antara lain tingkat pengetahuan, sikap, tingkat pendidikan, pelatihan, dan pengalaman kerja. Perawat profesional yang bertugas dalam memberikan pelayanan kesehatan tidak terlepas dari pengetahuan. Pengetahuan (knowledge) adalah hasil tahu dari manusia. Pengetahuan hanya dapat menjawab pertanyaan apa sesuatu itu. Sedangkan ilmu (science) dapat menjawab mengapa dan bagaimana sesuatu tersebut terjadi. Dengan demikian ilmu pengetahuan adalah salah satu dasar dari kehidupan manusia dalam memahami kehidupannya (Suyanto, 2011).
Perawat profesional yang bertugas di rumah sakit semakin diakui eksistensinya dalam setiap tatanan pelayanan kesehatan, sehingga dalam memberikan pelayanan secara interdependen tidak terlepas dari kepatuhan perawat dalam setiap prosedural seperti perawatan luka. Kepatuhan perawat merupakan perilaku perawat yang dapat di observasi dan dapat langsung diukur. Faktor yang berpengaruh terhadap tingkat kepatuhan antara lain pengetahuan, kemampuan, motivasi, masa kerja, latar belakang pendidikan, fasilitas atau peralatan, serta kejelasan prosedur (Wijayanti, 2013).

Salah satu ruang lingkup tugas perawat adalah membantu proses penyembuhan luka melalui perawatan luka. Perawatan luka merupakan tindakan keperawatan yang sering dilakukan di rumah sakit yang apabila tidak dilakukan sesuai dengan prosedur maka akan menyebabkan terjadinya infeksi klinis. Selain terjadinya infeksi, apabila tindakan perawatan luka tidak dilakukan sesuai dengan prosedur maka dapat menyebabkan berbagai komplikasi, diantaranya adalah syok yang ditandai dengan adanya perdarahan disertai perubahan tanda vital, dehiscene yaitu pecahnya luka sebagian atau seluruhnya yang ditandai dengan kenaikan suhu tubuh (demam), takikardia, dan rasa nyeri pada daerah luka, eviceration yaitu menonjolnya organ tubuh bagian dalam ke arah luar melalui luka yang dapat terjadi jika luka tidak segera menyatu dengan baik atau akibat proses penyembuhan yang lambat, hingga komplikasi yang lebih berat seperti kecacatan dan kematian (Alimul, 2006). Adapun tujuan dari perawatan luka adalah mencegah infeksi dari masuknya mikroorganisme ke dalam kulit, mencegah bertambahnya kerusakan jaringan, dan 
mempercepat penyembuhan (Hidayati et al., 2014).

World Health Organization (WHO) menyebutkan bahwa peristiwa kematian akibat kecelakaan lalu lintas di seluruh dunia sebesar 1,25 juta pada tahun 2013 di mana angka tersebut menetap sejak tahun 2007. Demikian pula di Indonesia, cedera kecelakaan lalu lintas dan kematian yang terjadi sudah menjadi masalah sangat serius (WHO, 2015).

Laporan dari Riset Kesehatan Dasar (RISKESDAS) tahun 2013 menunjukkan bahwa rata-rata prevalensi cedera luka terbuka sebesar $23,2 \%$ dengan kasus tertinggi terjadi pada laki-laki sebesar $26,6 \%$, untuk usia yang tertinggi pada rentang 25-34 tahun, dan jenis pekerjaan petani $29,2 \%$ dengan penyebab terbanyak karena benda tajam atau tumpul $12,6 \%$. Prevalensi jenis cedera luka terbuka menurut provinsi untuk provinsi Sumatera Selatan mencapai 18,7\% (RISKESDAS, 2013).

Hasil penelitian sebelumnya yang dilakukan oleh Fajar pada tahun 2014 menyatakan bahwa rata-rata hasil penelitian gambaran tingkat pengetahuan perawat tentang metode debridement pada luka kronik dari 110 responden, sebanyak 87 responden $(79,1 \%)$ menyatakan pengetahuannya kurang dan sebanyak 23 responden $(20,9 \%)$ menyatakan pengetahuannya baik. Sehingga dari data tersebut dapat disimpulkan bahwa rata-rata responden memiliki pengetahuan yang kurang dalam metode debridement pada luka kronik (Fajar, 2014).

Berdasarkan penelitian lain yang terkait, oleh Wijayanti pada tahun 2013 didapatkan hasil bahwa dari 34 responden, sebanyak 22 responden $(64,7 \%)$ menyatakan tidak patuh dan sebanyak 12 responden
(35,3\%) menyatakan patuh. Dari data tersebut menunjukkan bahwa sebagian besar responden tidak patuh dalam melaksanakan perawatan luka post operasi sesuai dengan standar prosedur operasional di RSUD Batang. Sehingga dapat disimpulkan ada hubungan motivasi dengan kepatuhan perawat pelaksana dalam melaksanakan perawatan luka post operasi sesuai dengan SOP di RSUD Batang, karena didapatkan $\rho$ value $=0,009$ (Wijayanti, 2013).

Berdasarkan data dan uraian diatas, dapat disimpulkan bahwa sebagian besar responden memiliki tingkat pengetahuan yang kurang dan tidak patuh dalam melaksanakan prosedur perawatan luka. Sehingga peneliti tertarik untuk melakukan penelitian dengan judul "Hubungan Tingkat Pengetahuan tentang Perawatan Luka terhadap Kepatuhan Perawat dalam Pelaksanaan Prosedur Perawatan Luka di Ruang Instalasi Gawat Darurat (IGD)".

\section{METODE PENELITIAN}

\section{Jenis Penelitian}

Penelitian ini merupakan penelitian kuantitatif, menggunakan metode analitik dengan pendekatan cross sectional.

\section{Waktu dan Tempat Penelitian}

Pengambilan data dilaksanakan pada 25 Maret 2019 s/d 29 April 2019 di Ruang Instalasi Gawat Darurat Rumah Sakit Pusri dan Rumah Sakit Islam Ar-Rasyid Palembang.

\section{Target/Subjek Penelitian}

Populasi penelitian ini adalah seluruh perawat di Rumah Sakit Pusri dan Rumah Sakit Islam Ar-Rasyid Palembang. Sampel 
penelitian ini adalah seluruh perawat di Ruang Instalasi Gawat Darurat Rumah Sakit Pusri dan Rumah Sakit Islam Ar-Rasyid Palembang yang berjumlah 30 responden. Teknik pengambilan sampel pada penelitian ini menggunakan teknik total sampling, dimana jumlah sampel sama dengan populasi.

\section{Data, Intrumen, dan Teknik Pengumpulan Data}

Pengumpulan data dilakukan menggunakan kuesioner yang diberikan langsung kepada responden dan meminta responden untuk menjawab dengan memberikan tanda ceklist untuk setiap jawaban serta lembar observasi yang digunakan untuk mengetahui kepatuhan perawat dalam melaksanakan prosedur perawatan luka.

\section{Teknik Analisis Data}

Analisis univariat dilakukan terhadap tiap-tiap variabel dari hasil penelitian yaitu variabel independen (pengetahuan perawat tentang perawatan luka) dan variabel dependen (kepatuhan perawat dalam melaksanakan prosedur perawatan luka) yang dianalisis dengan menggunakan tabel distribusi frekuensi.

Analisis bivariat, dilakukan untuk mengetahui ada tidak nya hubungan antara variabel independen (pengetahuan perawat tentang perawatan luka) dan variabel dependen (kepatuhan perawat dalam melaksanakan prosedur perawatan luka) menggunakan Uji Chi Square dengan derajat kemaknaan 0,05 . Bila nilai $\rho$ value $\leq$ $\alpha(0,05)$ berarti hasil perhitungan statistik bermakna (signifikasi), dan apabila nilai $\rho$ value $>\alpha ́ \alpha(0,05)$ berarti hasil perhitungan statistik tidak bermakna.

\section{HASIL PENELITIAN DAN PEMBAHASAN}

\section{Hasil Penelitian}

Hasil penelitian dijabarkan mulai dari deskripsi karakteristik responden, deskripsi pengetahuan perawat tentang perawatan luka dan deskripsi kepatuhan perawat dalam melaksanakan prosedur perawatan luka di Ruang Instalasi Gawat Darurat Rumah Sakit Pusri dan Rumah Sakit Islam Ar-Rasyid Palembang. Penelitian ini telah dilakukan pada tanggal 25 Maret 2019 s/d 29 April 2019 kepada 30 perawat di Ruang Instalasi Gawat Darurat Rumah Sakit Pusri dan Rumah Sakit Islam Ar-Rasyid Palembang.

\section{Analisis Univariat}

\section{a. Karakteristik Responden}

Deskripsi karakteristik responden mencakup jenis kelamin, usia, pendidikan, lama bekerja dalam pelayanan keperawatan dan keikutsertaan dalam pelatihan perawatan luka.

Hasil penelitian dari 30 responden yang terkumpul, didapatkan bahwa mayoritas responden yaitu berjenis kelamin perempuan sebanyak 18 orang (60\%), memiliki rentang usia dewasa awal 26-35 tahun sebanyak 14 orang $(46,7 \%)$, pendidikan terakhir D-III Keperawatan sebanyak 23 orang $(76,7 \%)$, lama bekerja dalam pelayanan keperawatan selama 1-10 tahun sebanyak 19 orang $(63,3 \%)$ dan responden dalam penelitian ini rata-rata belum pernah mengikuti pelatihan perawatan luka yaitu sebanyak 27 orang (90\%). Hasil tersebut dapat dilihat pada Tabel 1. 
Tabel 1. Distribusi Frekuensi dan Persentase Data Demografi Responden di Ruang IGD RS Pusri dan RSI Ar-Rasyid Palembang Tahun 2019 ( $N=30)$

\begin{tabular}{lcc}
\hline \multicolumn{1}{c}{ Karakteristik } & $\begin{array}{c}\text { Frekuensi } \\
(\mathbf{n})\end{array}$ & $\begin{array}{c}\text { Persentase } \\
(\%)\end{array}$ \\
\hline Jenis Kelamin & & \\
- Laki-laki & 12 & $40 \%$ \\
- Perempuan & 18 & $60 \%$ \\
\hline Usia & & \\
- 17-25 tahun & 10 & $33,3 \%$ \\
- 26-35 tahun & 14 & $46,7 \%$ \\
- 36-45 tahun & 6 & $20 \%$ \\
\hline Tingkat & & \\
Pendidikan & 23 & $76,7 \%$ \\
- D-III & 6 & $20 \%$ \\
- S1 & 1 & $3,3 \%$ \\
- S2 & & \\
\hline Lama Bekerja & & \\
dalam Pelayanan & & $20 \%$ \\
Keperawatan & 6 & $63,3 \%$ \\
- <1 tahun & 19 & $16,7 \%$ \\
- 1-10 tahun & 5 & \\
- 11-20 tahun & & \\
\hline Keikutsertaan & & \\
dalam Pelatihan & & \\
Perawatan Luka & & \\
(Wound Care) & 27 & \\
- Tidak pernah & 3 & \\
- Pernah & & \\
\hline
\end{tabular}

\section{b. Distribusi Frekuensi Pengetahuan Perawat tentang Perawatan Luka}

Hasil penelitian ini menunjukkan sebanyak 9 responden (30\%) memiliki pengetahuan baik, sebanyak 16 responden $(53,3 \%)$ memiliki pengetahuan cukup, dan 5 responden $(16,7 \%)$ memiliki pengetahuan kurang tentang perawatan luka di Ruang Instalasi Gawat Darurat Rumah Sakit Pusri dan Rumah Sakit Islam Ar-Rasyid
Palembang. Hasil tersebut dapat dilihat pada Tabel 2.

Tabel 2. Distribusi Frekuensi dan Persentase Tingkat Pengetahuan tentang Perawatan Luka di Ruang IGD RS Pusri dan RSI Ar-Rasyid Palembang Tahun 2019

\begin{tabular}{lcc}
\hline $\begin{array}{c}\text { Tingkat } \\
\text { Pengetahuan }\end{array}$ & $\begin{array}{c}\text { Frekuensi } \\
(\mathbf{n})\end{array}$ & $\begin{array}{c}\text { Persentase } \\
(\boldsymbol{\%})\end{array}$ \\
\hline - Baik & 9 & $30 \%$ \\
- Cukup & 16 & $53,3 \%$ \\
- Kurang & 5 & $16,7 \%$ \\
\hline Jumlah & 30 & $100 \%$ \\
\hline
\end{tabular}

c. Distribusi Frekuensi Kepatuhan Perawat dalam Melaksanakan Prosedur Perawatan Luka

Hasil penelitian ini didapatkan bahwa sebagian besar responden patuh dalam melaksanakan prosedur perawatan luka sebanyak 24 responden $(80 \%)$ dan sebanyak 6 responden (20\%) tidak patuh dalam melakukan prosedur perawatan luka di Ruang Instalasi Gawat Darurat Rumah Sakit Pusri dan Rumah Sakit Islam ArRasyid Palembang. Hasil tersebut dapat dilihat pada Tabel 3.

Tabel 3. Distribusi Frekuensi dan Persentase Kepatuhan Perawat dalam Melaksanakan Prosedur Perawatan Luka di Ruang IGD RS Pusri dan RSI Ar-Rasyid Palembang Tahun 2019

\begin{tabular}{lcc}
\hline Kepatuhan & $\begin{array}{c}\text { Frekuensi } \\
(\mathbf{n})\end{array}$ & $\begin{array}{c}\text { Persentase } \\
(\boldsymbol{\%})\end{array}$ \\
\hline - Patuh & 24 & $80 \%$ \\
- Tidak Patuh & 6 & $20 \%$ \\
\hline Jumlah & 30 & $100 \%$ \\
\hline
\end{tabular}




\section{Analisis Bivariat}

\section{Tabel 4. Hubungan Tingkat Pengetahuan Tentang Perawatan Luka terhadap Kepatuhan Perawat dalam Pelaksanaan Prosedur Perawatan Luka di Ruang IGD RS Pusri dan RSI Ar-Rasyid Palembang Tahun 2019}

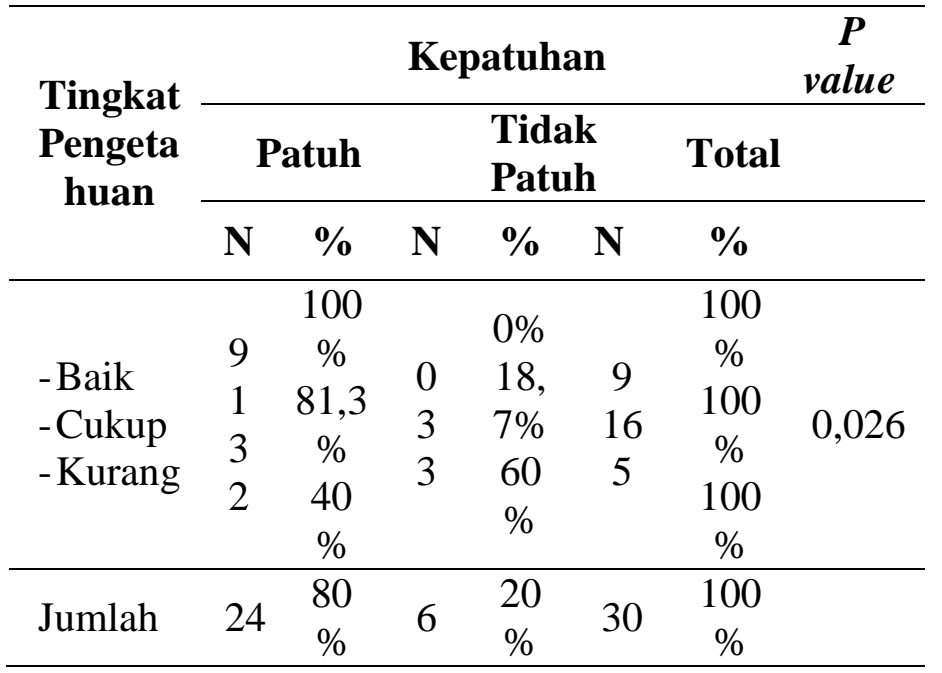

Hasil analisis dari tabel 4. didapatkan bahwa sebagian besar responden memiliki tingkat pengetahuan cukup yaitu 16 $(100,0 \%)$, dimana terdapat $13 \quad(81,3 \%)$ responden patuh terhadap prosedur perawatan luka, dan $3(18,7 \%)$ responden tidak patuh terhadap prosedur perawatan luka. Responden yang memiliki tingkat pengetahuan baik yaitu $9(100,0 \%)$, dimana keseluruhan total responden yaitu $9(100 \%)$ responden patuh terhadap prosedur perawatan luka, dan $0(0 \%)$ responden tidak patuh terhadap prosedur perawatan luka. Sedangkan responden yang memiliki pengetahuan kurang baik yaitu 5 (100,0\%), dimana terdapat $2(40 \%)$ patuh terhadap prosedur perawatan luka, dan $3(60 \%)$ responden tidak patuh terhadap prosedur perawatan luka.
Hasil uji statistik diperoleh nilai $P$ value $=0,026$ yang berarti $\mathrm{p}<\alpha=0,05$, maka dapat disimpulkan bahwa ada hubungan tingkat pengetahuan tentang perawatan luka terhadap kepatuhan perawat dalam pelaksanaan prosedur perawatan luka di Ruang Instalasi Gawat Darurat Rumah Sakit Pusri dan Rumah Sakit Islam ArRasyid Palembang tahun 2019.

\section{Pembahasan}

\section{Analisis Univariat}

\section{a. Karakteristik Responden}

Distribusi Frekuensi dan Persentase Data Demografi Responden didapatkan hasil bahwa mayoritas responden yaitu berjenis kelamin perempuan sebanyak 18 orang $(60 \%)$, memiliki rentang usia dewasa awal 26-35 tahun sebanyak 14 orang $(46,7 \%)$, pendidikan terakhir D-III Keperawatan sebanyak 23 orang $(76,7 \%)$, lama bekerja dalam pelayanan keperawatan selama 1-10 tahun sebanyak 19 orang $(63,3 \%)$ dan responden dalam penelitian ini rata-rata belum pernah mengikuti pelatihan perawatan luka yaitu sebanyak 27 orang $(90 \%)$.

Data jenis kelamin responden mayoritas berjenis kelamin perempuan sebanyak 18 responden (60\%). Dewasa ini seorang wanita memiliki motivasi tinggi dari pada kaum laki-laki, hal ini disebabkan karena motif untuk mengejar karir kerja, disamping tanggung jawab keluarga yang dibebankan pada seorang wanita sebagai seorang istri atau ibu untuk merawat anaknya, namun pada saat ini wanita untuk mencapai karir yang diharapkan, seorang wanita akan berusaha semaksimal mungkin bekerja keras dan tidak menjadikan gender sebagai halangan dalam pekerjaan (Imam, 2018). 
Presentase usia responden sebagian besar memiliki rentang usia dewasa awal 2635 tahun sebanyak 14 orang $(46,7 \%)$. Usia merupakan lamanya hidup yang dihitung sejak lahir sampai saat ini. Usia dapat mempengaruhi terhadap daya tangkap dan pola pikir seseorang, semakin bertambah usia maka semakin bertambah pula daya tangkap dan pola pikirnya. Maka dari itu, pengetahuan yang diperolehnya semakin membaik (Notoatmodjo, 2012). Menurut peneliti, usia seseorang sering kali dikaitkan dengan pengetahuan orang tersebut, karena semakin bertambahnya usia, maka informasi dan pengalaman yang didapat pun akan semakin bertambah, sehingga hal tersebut otomatis akan berdampak pada bertambahnya pengetahuan dan pengalaman yang dimiliki sehingga seseorang akan lebih patuh.

Data pendidikan terakhir responden yaitu paling banyak lulusan D-III keperawatan sebanyak 23 orang $(76,7 \%)$. Pada dasarnya semakin tinggi pendidikan seseorang, semakin mudah orang tersebut untuk menerima informasi. Dengan pendidikan tinggi maka seseorang akan cenderung untuk mendapatkan informasi, baik dari orang lain maupun dari media massa. Semakin banyak informasi yang masuk semakin banyak pula pengetahuan yang didapat (Imam, 2018).

Presentase lama bekerja dalam pelayanan keperawatan sebagian besar selama 1-10 tahun sebanyak 19 orang $(63,3 \%)$ Pengalaman merupakan aspek terpenting dalam proses pembelajaran yang dapat berimplikasi positif menambah pengetahuan seseorang terhadap suatu hal. Pengalaman kerja 1-10 tahun dalam keperawatan memiliki tingkat pengetahuan yang jauh lebih baik dibandingkan dengan pengalaman kerja 11-20 tahun. Perawat dengan tahun kerja lebih lama memiliki kesempatan lebih rendah meng-update ilmunya (Widya, 2015).

Pada penelitian ini sebanyak 27 orang $(90 \%)$ responden belum pernah mengikuti pelatihan tentang perawatan luka (Wound Care). Sumber informasi bisa didapatkan melalui pelatihan-pelatihan yang dilakukan. Pelatihan merupakan salah satu sumber informasi yang menjadi perantara dalam menyampaikan informasi, merangsang pikiran dan kemampuan, dan menambah pengetahuan (Notoatmodjo, 2012). Dari data yang diperoleh rata-rata responden sudah pernah mengikuti pelatihan selain pelatihan perawatan luka (Wound Care) seperti pelatihan Basic Trauma Cardiac Life Support (BTCLS), Bantuan Hidup Dasar (BHD), Pertolongan Pertama Gawat Darurat (PPGD), Interpretasi EKG, Spiritual Emotional Freedom Technique (SEFT), Phlebotomy, Manajemen Stroke, Manajemen Terpadu Balita Sakit (MTBS), dan Mahir ICU Dewasa. Pelatihan-pelatihan tersebut telah difasilitasi oleh rumah sakit.

\section{b. Tingkat Pengetahuan tentang Perawatan Luka}

Dari hasil analisis didapatkan bahwa sebagian besar responden di Rumah Sakit Pusri dan Rumah Sakit Islam Ar-Rasyid Palembang memiliki tingkat pengetahuan cukup sebanyak 16 responden $(53,3 \%)$. Hal ini dapat diasumsikan bahwa pengetahuan responden tentang perawatan luka tergolong sudah cukup baik karena data menunjukkan mayoritas responden memiliki pengetahuan cukup $(53,3 \%)$ dan baik $(30 \%)$. Tingkat pengetahuan perawat yang cukup baik ini didukung oleh adanya sosialisasi metode perawatan luka sehingga perawat yang bekerja di Ruang Instalasi Gawat Darurat Rumah Sakit Pusri dan Rumah Sakit Islam Ar-Rasyid Palembang telah mampu memahami teknik perawatan luka. 
Berdasarkan hasil penelitian bahwa baiknya pengetahuan perawat tentang perawatan luka dipengaruhi oleh informasi yang diperoleh baik dari pendidikan formal maupun nonformal (pendidikan, pelatihan atau pengalaman) yang dapat memberikan pengaruh jangka pendek sehingga menghasilkan perubahan atau peningkatan pengetahuan.

Sejalan dengan penelitian yang dilakukan oleh (Widya, 2015), hasil penelitan menunjukkan bahwa setengah dari total responden $(50 \%)$ perawat memiliki pengetahuan cukup baik tentang perawatan luka dengan metode moist wound healing.

Dari hasil penelitian ini masih ditemukan $5(16,7 \%)$ responden memiliki pengetahuan yang kurang baik tentang perawatan luka. Menurut peneliti, masih kurangnya pengetahuan perawat dikarenakan pengalaman yang dimilikinya juga masih kurang dimana 6 perawat memiliki masa kerja kurang dari 1 tahun sehingga mereka belum terlatih dengan baik dibandingkan 24 perawat yang memiliki pengalaman kerja lebih dari 1 tahun.

Dari pembahasan diatas, peneliti dapat menyimpulkan bahwa pengetahuan responden tentang perawatan luka tergolong sudah cukup baik (53,3\%). Pengetahuan perawat yang baik dipengaruhi oleh informasi yang didapatkan melalui pelatihan-pelatihan yang dilakukan dan pengalaman kerja, sehingga keduanya dapat menambah pengetahuan dan wawasan kepada responden.

\section{c. Kepatuhan Perawat dalam Melaksanakan Prosedur Perawatan Luka}

Dari hasil analisis didapatkan bahwa sebagian besar responden di Rumah Sakit
Pusri dan Rumah Sakit Islam Ar-Rasyid Palembang patuh dalam melaksanakan prosedur perawatan luka sebanyak 24 responden $(80 \%)$. Hal ini dipengaruhi oleh pengetahuan dimana pengetahuan yang baik akan mempengaruhi kepatuhan perawat dalam melaksanakan prosedur perawatan luka.

Sejalan dengan penelitian yang dilakukan oleh Imam (2018), didapatkan hasil bahwa tingkat kepatuhan responden sebagian besar patuh (72\%) dan tidak terjadi infeksi (67\%). Hasil tabulasi silang diperoleh nilai ( $p=0.000)$ yang berarti bahwa Ada hubungan kepatuhan perawat dalam pelaksanaan standar operasional prosedur perawatan luka operasi dengan kejadian infeksi luka operasi section caesaria di ruang X Rumah Sakit Umum Daerah Ciawi.

Kepatuhan seorang perawat dapat dipengaruhi oleh faktor internal dan eksternal, seperti usia, pendidikan, pengetahuan, masa kerja, fasilitas atau peralatan, serta kejelasan prosedur. Pengetahuan merupakan faktor pendukung penting yang harus dimiliki oleh setiap perawat karena pengetahuan yang baik dapat membawa seseorang melakukan suatu tindakan yang optimal (Wijayanti, 2013).

Dalam penelitian ini masih terdapat $6(20 \%)$ responden yang tidak patuh dalam melaksanakan prosedur perawatan luka. Menurut peneliti, hal ini disebabkan oleh kondisi lingkungan fisik yang tidak mendukung, misal peralatan yang tidak mencukupi, suasana yang berisik, ventilasi udara kurang baik, maka motivasi untuk meningkatkan prestasi akan melemah. Dimana lingkungan kerja berpengaruh besar pada kepatuhan.

Dari pembahasan diatas, peneliti dapat menyimpulkan bahwa sebagian besar 
perawat Rumah Sakit Pusri dan Rumah Sakit Islam Ar-Rasyid Palembang dikategorikan patuh dalam melaksanakan prosedur perawatan luka. Hal ini disebabkan karena pengetahuan yang cukup baik dan kesadaran diri perawat dalam melakukan setiap tindakan berpacu pada Standar Operasional Prosedur (SOP) yang telah ditetapkan oleh pihak rumah sakit.

\section{Analisis Bivariat}

Dari hasil analisis didapatkan bahwa nilai $p$ value $=0,026$ yang berarti $\mathrm{p}<\alpha=$ 0,05, maka dapat disimpulkan bahwa ada hubungan tingkat pengetahuan tentang perawatan luka terhadap kepatuhan perawat dalam pelaksanaan prosedur perawatan luka. pengetahuan yang baik dapat mempengaruhi kepatuhan perawat dalam melaksanakan prosedur perawatan luka. Hasil penelitian ini mendukung teori yang dikemukakan oleh Wijayanti (2013) bahwa kepatuhan perawat dipengaruhi oleh usia, latar belakang pendidikan, pengetahuan, masa kerja, fasilitas atau peralatan, serta kejelasan prosedur.

Sejalan dengan penelitian yang dilakukan oleh Andri (2016), yang berjudul hubungan tingkat pengetahuan tentang perawatan luka dengan kepatuhan perawat dalam melaksanakan prosedur perawatan luka. Hasil penelitian menunjukkan bahwa ada hubungan tingkat pengetahuan tentang perawatan luka dengan kepatuhan perawat dalam melaksanakan prosedur perawatan luka di ruang gelatik dan kutilang RSUD Dr. H. Abdul Moeloek Bandar Lampung tahun 2016. Hasill uji statistik diperoleh nilai $p$ value $=0,041$ yang berarti $p<\alpha=0,05$. Dengan nilai OR 6,9 berarti responden yang tingkat pengetahuan kurang baik memiliki peluang 6,9 kali lebih besar tidak patuh dalam melaksanankan prosedur perawatan luka disbanding dengan responden yang berpengetahuan baik dengan nilai $95 \%$ CI $1,1-40,9$.

Hasil penelitian ini didapatkan bahwa sebagian besar responden memiliki tingkat pengetahuan cukup yaitu 16 $(100,0 \%)$, dimana terdapat $13(81,3 \%)$ responden patuh terhadap prosedur perawatan luka, dan $3(18,7 \%)$ responden tidak patuh terhadap prosedur perawatan luka. Responden yang memiliki tingkat pengetahuan baik yaitu $9(100,0 \%)$, dimana keseluruhan total responden yaitu 9 (100\%) responden patuh terhadap prosedur perawatan luka. Sedangkan responden yang memiliki pengetahuan kurang baik yaitu 5 $(100,0 \%)$, dimana terdapat 2 (40\%) responden patuh terhadap prosedur perawatan luka, dan $3(60 \%)$ responden tidak patuh terhadap prosedur perawatan luka. Angka ini tidak cukup banyak dari responden yang dijadikan sampel. Hal ini menunjukkan bahwa responden sebagian besar sudah patuh dalam melaksanakan tindakan perawatan luka sesuai prosedur.

Dari pembahasan diatas, didapatkan hasil bahwa nilai $p$ value $=0,026$ yang berarti $\mathrm{p}<\alpha=0,05$, maka dapat disimpulkan bahwa ada hubungan tingkat pengetahuan tentang perawatan luka terhadap kepatuhan perawat dalam pelaksanaan prosedur perawatan luka. Peneliti berasumsi bahwa semakin baik pengetahuan seorang perawat, maka semakin patuh pula seorang perawat dalam melaksanakan prosedur perawatan luka.

Penelitian ini dapat menjadi acuan pihak rumah sakit agar perlu meningkatkan kualitas pelayanan dan pengembangan pengetahuan perawat disertai pendidikan dan pelatihan perawatan luka kepada semua perawat agar kepatuhan dalam melaksanakan tindakan perawatan luka dilakukan sesuai prosedur. 


\section{KESIMPULAN}

1. Berdasarkan hasil penelitian yang dilakukan di Ruang Instalasi Gawat Darurat Rumah Sakit Pusri dan Rumah Sakit Islam Ar-Rasyid Palembang Tahun 2019, mayoritas responden yaitu berjenis kelamin perempuan sebanyak 18 orang (60\%), memiliki rentang usia dewasa awal 26-35 tahun sebanyak 14 orang $(46,7 \%)$, pendidikan terakhir D-III Keperawatan sebanyak 23 orang (76,7\%), lama bekerja dalam pelayanan keperawatan selama 1-10 tahun sebanyak 19 orang $(63,3 \%)$ dan responden dalam penelitian ini rata-rata belum pernah mengikuti pelatihan perawatan luka yaitu sebanyak 27 orang $(90 \%)$.

2. Sebagian besar pengetahuan responden tentang perawatan luka cukup baik, yaitu sebanyak 16 responden $(53,3 \%)$.

3. Sebagian besar responden patuh dalam melaksanakan prosedur perawatan luka sebanyak 24 responden ( $80 \%)$.

4. Ada hubungan yang bermakna antara tingkat pengetahuan tentang perawatan luka terhadap kepatuhan perawat dalam pelaksanaan prosedur perawatan luka di Ruang Instalasi Gawat Darurat Rumah Sakit Pusri dan Rumah Sakit Islam ArRasyid Palembang tahun 2019 dengan $p$ value $=0,026$ yang berarti $p<\alpha=0,05$.

5. Semakin baik pengetahuan seorang perawat, maka semakin patuh pula seorang perawat dalam melaksanakan prosedur perawatan luka.

\section{SARAN}

\section{Bagi Manajemen Rumah Sakit}

Hasil penelitian ini dapat memberikan hubungan yang bermakna antara tingkat pengetahuan tentang perawatan luka terhadap kepatuhan perawat dalam pelaksanaan prosedur perawatan luka di Ruang Instalasi Gawat Darurat Rumah Sakit Pusri dan Rumah Sakit Islam ArRasyid Palembang. Melalui hasil penelitian ini disarankan bagi pihak Rumah Sakit Pusri dan Rumah Sakit Islam Ar-Rasyid Palembang agar dapat memfasilitasi pelatihan perawatan luka pada perawat. Hasil data demografi responden menunjukkan bahwa sebagian besar perawat belum pernah mendapatkan pelatihan perawatan luka dari rumah sakit. Hal tersebut yang menyebabkan masih ada beberapa perawat yang memiliki pengetahuan kurang baik dan tidak mengetahui tentang perawatan luka.

\section{Bagi Perawat}

Diharapkan tenaga kesehatan khususnya perawat agar dapat menerapkan asuhan keperawatan dalam melaksanakan tindakan perawatan luka sesuai dengan SOP yang berlaku sehingga tidak akan terjadinya komplikasi pada area luka tersebut.

\section{Bagi Institusi Pendidikan}

Hasil penelitian ini dapat menjadi sumber informasi dalam pendidikan ilmu keperawatan tentang perawatan luka. Sebagai tempat menggali ilmu keperawatan, institusi pendidikan keperawatan diharapkan dapat mendukung dan memfasilitasi seminar ataupun pelatihan yang diberikan kepada rumah sakit agar adanya kesinambungan antara pengetahuan yang diperoleh di institusi pendidikan keperawatan dengan tindakan praktik yang dilaksanakan di rumah sakit.

\section{Bagi Peneliti Selanjutnya}

Diharapkan peneliti selanjutnya dapat melaksanakan penelitian dengan menggunakan sampel yang lebih banyak 
lagi dan waktu yang diperlukan \pm 2 bulan sehingga bisa dilihat perbandingannya dan diharapkan mendapatkan hasil yang lebih baik lagi.

\section{UCAPAN TERIMA KASIH}

Penulis mengucapkan terima kasih kepada semua pihak yang telah membantu, memberikan bimbingan, dorongan ataupun saran-saran dalam menyelesaikan skripsi ini. Pada kesempatan ini penulis mengucapkan banyak terima kasih kepada yang terhormat:

1. Ibu Diana H.Soebyakto, M.Kes, selaku Ketua STIKES Mitra Adiguna Palembang.

2. Bapak Drs. Bambang B.Soebyakto, M.A.PhD, selaku Ketua II Bidang Non Akademik STIKES Mitra Adiguna Palembang.

3. Ibu Ns. Leni Wijaya, S.Kep, M.Kes, selaku Ketua Program Studi S1 Keperawatan STIKES Mitra Adiguna Palembang.

4. Bapak Ns. Oscar Ari Wiryansyah, S.Kep, M.Kep, selaku dosen pembimbing skripsi.

5. Ibu Ns. Fera Siska, S.Kep, M.Kes, selaku dosen penguji I.

6. Ibu Ns. Lisda Maria, S.Kep, M.Kep, selaku dosen penguji II.

7. Bapak Prof. Dr. dr. H. Yuwono, M. Biomed, selaku Direktur Rumah Sakit Pusri Palembang yang telah memberikan izin dalam penelitian ini.

8. Bapak KOL. CKM(P). dr. Toni Siguntang, Sp.THT-KL., MARS, selaku Direktur Rumah Sakit Islam Ar-Rasyid Palembang yang telah memberikan izin dalam penelitian ini.

\section{DAFTAR PUSTAKA}

Alimul, Hidayat. 2006. Pengantar Kebutuhan Dasar Manusia: Aplikasi
Konsep dan Proses Keperawatan. Jakarta: Salemba Medika.

Arikunto, S. 2008. Prosedur penelitian: Suatu pendekatan praktik. Edisi Revisi VI. Jakarta : Rineka Cipta.

Badan Penelitian dan Pengembangan Kesehatan, Kemkes RI. 2013. Angka Kejadian Luka Provinsi Sumatera Selatan. Jakarta: Bakti Husada.

Budiman dan Riyanto, A. 2014. Kapita selekta kuesioner pengetahuan dan sikap dalam penelitian. Jakarta: Salemba Medika.

Depkes RI. 2004. Sistem Kesehatan Nasional. Jakarta: DepKes.

Devi dan Wijayanti. 2013. Hubungan Motivasi dengan Kepatuhan Perawat Pelaksana dalam Melaksanakan Perawatan Luka Post Operasi Sesuai dengan SOP Di RSUD Batang. Jurnal Penelitian.

Ekaputra, Erfandi. 2013. Evolusi Manajemen Luka. Jakarta: Trans Info Media.

Fajar, Kana dan Waluyo, Agung. 2014. Gambaran Tingkat Pengetahuan Perawat Tentang Metode Debridement pada Luka Kronik. Jurnal Penelitian.

Hidayat, A. 2014. Metode Penelitian dan Teknik Analisis Data. Jakarta: Salemba Medika.

Hidayati, R., Huda, M., Hayati, Farida., Setyorini, D. 2014. Praktik Laboratorium Keperawatan Jilid II. Jakarta: Erlangga.

Kartikawati, Dewi. 2011. Buku Ajar Dasardasar Keperawatan Gawat Darurat. Jakarta: Salemba Medika. 
Munandar, Imam. 2018. Kepatuhan Perawat dalam Pelaksanaan Standar Operasional Prosedur (SOP) Perawatan Luka dengan Kejadian Infeksi Luka Operasi Post Sectio Caesaria. Jurnal Penelitian.

Naralia, Widya. 2015. Pengetahuan Perawat Tentang Perawatan Luka dengan Metode Moist Wound Healing di RSUP H. Adam Malik Medan. Jurnal Penelitian.

Notoatmodjo, Soekidjo. 2012. Promosi Kesehatan dan Perilaku Kesehatan.. Jakarta: Rineka Cipta.

Notoatmodjo, Soekidjo. 2012. Metodelogi Penelitian Kesehatan. Jakarta: Rineka Cipta.

Nursalam. 2009. Konsep dan penerapan metodologi penelitian ilmu keperawatan : Pedoman skripsi, tesis dan instrumen penelitian keperawatan. Jakarta: Salemba Medika.

Pamuji, T., Asrin., Kamaludin, R. 2008. Hubungan Pengetahuan Perawat Tentang Standar Prosedur Operasional (SPO) dengan Kepatuhan Perawat Terhadap Pelaksanaan SPO Profesi Pelayanan Keperawatan di Instalasi Rawat Inap RSUD Purbalingga. Jurnal Penelitian.

Patmawati, Windi. 2015. Gambaran Pengetahuan Remaja Putri Tentang Status Gizi di Smp Muhammadiyah 03 Tanjung Sari Tahun 2015. Jurnal Penelitian.
Setiadi. 2013. Konsep \& Penulisan Riset Keperawatan. Yogyakarta: Graha Ilmu.

Setianingsih, Ratna. 2014. Perbedaan Tingkat Kepatuhan Penggunaan Alat Pelindung Diri (APD) pada Perawat Bangsal Kelas Non Utama dan Utama di Rumah Sakit Wijayakusuma Purwokerto. Jurnal Penelitian.

Sharanjit., Nasution, I., Hayati, L. 2015. Angka Kejadian Korban Kecelakaan Lalu Lintas Berdasarkan Hasil Pemeriksaan Luar Visum Et Repertum Di RSUP Dr. Mohammad Hoesin Palembang Tahun 2011-2013. Jurnal Penelitian.

Susilawati, Desy. 2016. Ini Penyebab Sebagian Besar Pasien Masuk IGD. https://republika.co.id/berita/gayahidup/info-sehat/16/09/19/odq62a328-inipenyebab-sebagian-besar-pasien-masukigd. (diakses pada tanggal 11 Februari 2019).

Suyanto. 2011. Metodologi dan Aplikasi Penelitian Keperawatan. Yogyakarta: Nuha Medika.

Undang-undang RI Nomor 44 Tahun 2009 Tentang Rumah Sakit.

World Health Organization, 2015. Global Status Report on Road Safety, WHO Librar. ed. doi:978 $92 \quad 4 \quad 1565066$. WHO/NMH/NVI/15.6

Yulianto, Andri. 2016. Hubungan Tingkat Pengetahuan Tentang Perawatan Luka dengan Kepatuhan Perawat dalam Melaksanakan Prosedur Perawatan Luka. Jurnal Penelitian. 